\title{
Nationale sportsstereotyper i dansk sportspresse, 1980-2004
}

\author{
Af Michael Eriksen
}

Da det danske fodboldlandshold i 1992 besejrede Tyskland i EM-finalen, indledtes straks en sand folkefest $i$ hele landet. Også den danske presse festede med. Aviserne bugnede af lovord om de danske helte, der havde skudt den tyske ørn ned ${ }^{1}$, og besejret de ellers så sejrsvante jernmænd fra Tyskland $^{2}$. Tilbage i 1986 var billedet det samme. Under VM i Mexico havde reservemålmanden Lars Høgh således formået at stække den tyske ørn, i sandhed noget af en bedrift, idet pressen mente, at de tyske alvorsmænd havde anvendt deres Panzer-næver mod danskerne i 2. halvleg. ${ }^{3}$

Sport og særligt fodbold har siden midten af det 20. århundrede optaget mere og mere spalteplads i aviserne. ${ }^{4}$ Der laves interviews med spillere og trænere, og der spekuleres over kampenes mulige udfald. Alle disse vigtige informationer tilgår læserne $\mathrm{i}$ en lind strøm året rundt, svøbt $i$ en helt særlig sportsjournalistisk jargon. Et centralt element $i$ denne jargon er de nationale sportsstereotyper, der meget præcist fremhæver bestemte karakteristika hos landsholdene. Disse stereotyper har to sider. På den ene side hjælper de os som individer med at navigere $\mathrm{i}$ en værdifragmenteret verden. ${ }^{5}$ På den anden side er stereotyperne, efter alt at dømme, medvirkende til at skabe og vedligeholde fordomme, som citaterne ovenover muligvis er et udtryk for. ${ }^{6}$ Spørgsmålet er, i hvilket omfang de ovennævnte citater er kendetegnende for den danske sportspresses fremstilling af Tyskland. Det er det, der skal undersøges i denne artikel, hvor de nationale sportsstereotyper, som den danske sportspresse har benyttet over for Tyskland, England og Spanien i perioden 1980-2004 identificeres. Det skal i forlængelse heraf diskuteres, hvilke årsager der kan ligge til grund for deres udseende.

\section{Content analysis}

Analysen dækker således tiden 1980-2004. Det er i denne periode, det danske fodboldlandshold begynder at få sportslig succes, hvad der står i skærende kontrast til ørkenvandringen i 1970'erne. Det medfører øget pressefokus på fodboldlandsholdet, og da der samtidig i dette tidsrum er afviklet et stort antal landskampe mellem det danske landshold og de tre lande, betyder dette, at der er rigelig med empiri at tage af ${ }^{7}$.

Der har primært været brugt følgende kriterier i valget af aviserne til analysen, nemlig 1) de skulle være landsdækkende, og 2) så blev der tilstræbt en vis spredning $\mathrm{i}$ politisk observans, hvorfor Politiken, Berlingske Tidende, BT, Ekstra Bladet og Jyllands-Posten er udvalgt. Hvad angår selve analysen, så fokuserer den på artiklerne dagen efter kampene. ${ }^{8}$ Samtlige landskamprelaterede artikler er blevet analyseret, hvad 
enten de har været trykt på forsiden eller i selve sportssektionen. ${ }^{9}$

Endelig er stereotyperne i det følgende alle identificeret ved hjælp af den metodiske tilgang content analysis. Dette analyseredskab er anvendt til at udpege en række hovedkategorier indeholdende underkategorier, hvori de sproglige udsagn efterfølgende er placeret. På den måde er en række stereotype træk ved sportspressens fremstilling af de enkelte lande trådt frem. I alt fem hovedkategorier er identificeret. 1) Mentale egenskaber indeholder beskrivelser om spillernes mentale færdigheder, 2) Fysiske egenskaber refererer til spillernes fysik, 3) $\mathrm{Na}$ tionale aspekter indeholder historiske referencer samt beskrivelser af landenes tilhængere, 4) Spillet på banen beskriver, hvorledes sportspressen opfatter landsholdets fodboldmæssige formåen, og endelig 5) Spillets struktur beskriver, hvorledes det enkelte landshold strukturerer spillet på banen. Der er således et mentalstereotypisk billede af tyskerne, en fysisk stereotyp osv. ${ }^{10}$

\section{Forskningen inden for nationale sportsstereotyper}

Der foreligger ikke undersøgelser af nationale sportsstereotypers optræden i dansk sportspresse, men internationalt set er der foretaget en række analyser. Fokus har med ganske få undtagelser været på fodboldsporten $^{11}$, og de gennemførte analyser har ofte været trykt i medie- eller sportsantologier. ${ }^{12}$ Diverse EM- og VM-turneringer i 1990'erne har været analyseret ${ }^{13}$, ligesom klubkampe har været inddraget i mindre grad. ${ }^{14}$

De nationale stereotyper, som den europæiske sportspresse anvender til at beskrive Tyskland, er påfaldende identiske på tværs af landegrænser. Tyskerne fremstilles således som stærke, effektive, disciplinerede, militaristiske og aggressive. ${ }^{15}$ De er organiserede, arbejder hårdt, heldige, mekaniske, fantasiløse, og så er de meget selvsikre. Forskningen har forklaret disse tyske stereotyper ud fra primært, 1) de to verdenskrige, særligt den Anden, og Tysklands centrale rolle heri, 2) det tyske økonomiske wirtschaftswunder efter 2. Verdenskrig, 3) Tysklands sportslige dominans og 4) et ønske i pressen om at opretholde Tyskland primært og Centraleuropa sekundært som vækstens centrum og drivkraften bag fortsat økonomisk fremgang i Europa.

Englænderne fremstilles i den europæiske sportspresse som et fysisk stærkt hold, der har viljestyrke, og som kæmper til sidste mand. ${ }^{16}$ Herudover findes der - særligt i den franske presse - en fascination af det britiske kongehus, når engelske spillere gentagne gange omtales som royale. ${ }^{17}$ Spillerne er ifølge spansk og fransk presse samtidig arrogante, og de lever i fortiden, $\mathrm{i}$ mangel på succes i nutiden..$^{18}$ Ofte portrætteres englænderne også som voldsmænd og rå spillertyper, navnlig i den spanske sportspresse. ${ }^{19}$ Ifølge forskningen er der overordnet set fem forklaringer, som ligger til grund for disse stereotypers udseende: 1) 2. Verdenskrig, 2) de engelske hooligans, 3) det engelske kongehus, 4) det isolerede kongedømme og 5) fordums storhed - sportsligt og politisk.

Spanierne beskrives ofte som brutale, grænsende til det dyriske. ${ }^{20}$ De har et iltert temperament, som de sjældent kan styre, og ved enhver given lejlighed forsøger de at snyde sig til dommerkendelser. ${ }^{21}$ Når de oplever modgang, bliver de dovne og humørforladte. Samtidig snubler de altid på målstregen, når de stiller op til en stor turnering. Spanien fremstilles som et lige ved og 
næsten-landshold. Baggrunden for stereotypernes udseende skal ifølge forskningen findes i 1) Spaniens kærlighed til tyrefægtning, 2) landsholdets manglende sportslige succes, 3) Den Spanske Armadas fejlslagne invasion af de britiske øer i 1588, og 4) opretholdelsen af Sydeuropa som et underudviklet område.

Sammenfattende kan der siges, at stereotyperne ligner hinanden på tværs af landegrænserne, men der er dog også lokale forskelle. Hvad angår årsagsforklaringerne, deler disse sig i to hovedkategorier: Sociokulturelle forklaringer på den ene side og sportslige, fodboldinterne forklaringer på den anden. ${ }^{22}$

\section{Sportspressens udvikling}

Siden 2. Verdenskrig er omfanget af sport i den europæiske sportspresse vokset. Fra tidligere at referere kampene ned i mindste detalje, fokuseres der nu i højere grad på skæve vinkler og personstof. ${ }^{23}$ Avisernes sportssektioner skal nemlig ikke længere genfortælle kampen, idet læserne sikkert selv har set den på tv. Alligevel er artiklerne ikke blevet mindre - tværtimod. ${ }^{24}$ Også sproget er forandret. Sproget er med til at sælge avisen over for læserne-eksempelvis må en kedelig kamp aldrig fremstå søvndyssende. ${ }^{25}$ For at undgå dette, benyttes et sprog og et ordvalg, der sprænger de rammer, der anvendes og tillades i resten af avisen. Tyskerne kan således fint bombe det danske forsvar, uden at denne beskrivelse støder læserne, hvorimod en statsminister, der tæppebomber oppositionen og fører lynkrig mod Socialdemokraterne, sandsynligvis ville skabe visse misforståelser rundt i de danske hjem ${ }^{26}$.

\section{Den danske presses doekning af landskampene mod England, Tyskland og Spanien 1980- 2004}

\section{Den engelske løve}

Hvis vi ser på styrkeforholdet mellem det danske og det engelske landshold, er det forholdsvist jævnbyrdigt. Analysen omfatter i alt ni kampe, og der har været point på spil i fire tilfælde, med én dansk og én engelsk sejr, samt to uafgjorte. De resterende fem kampe har alle været venskabskampe, og her har Danmark vundet én, tabt tre og spillet én uafgjort. Pressens mentalstereotype billede af englænderne fremstiller dem som aggressive og frustrerede spillere. Som BT skrev om danske Flemming Povlsens spil i 1990 mod England, så er »Man (...) altid sikker på en indsats, når unge Povlsen er på banen. Men der kom ikke meget ud af tirsdagens anstrengelser. Englaenderne var for hurtige og aggressive til, at han $i$ sin nuvarende form kunne true dem « ${ }^{27}$ Som citatet viser, er englænderne i besiddelse af et aggressivt drive, men går det ikke som forventet, bliver de frustrerede som under EM i 1992, hvor Danmark var oppe mod England. Kampen endte 0-0, bl.a. fordi »englanderne blev frustrerede og sløsede med markeringerne« i 2 . halvleg. ${ }^{28}$ Pressen beskriver englændernes fysiske færdigheder som hurtige og besiddende styrke. På Berlingske Tidende havde man straks efter det uafgjorte resultat mod England i Idrætsparken i 1982 fat i manden bag det udlignende mål til 2-2, lille Jesper Olsen, der om scoringsøjeblikket fortalte: »Jeg blev et ganske kort øjeblik nervøs - jeg havde set, hvor hurtigt Shilton hver gang kom ud af sit mål. Men så skyndte jeg mig at sparke«. ${ }^{29}$ Nogle 
år senere, i maj 1990, tabte Danmark 0-1 på Wembley, og Berlingske Tidende beskrev, hvorledes $» d e$ [englcenderne] overtog mere og mere af spillet $i$ lystige, hurtige kombinationer med Gascoigne og Waddle som bindeled til fronten, John Barnes og Lineker $\ll .^{30}$ Ved siden af denne hurtighed som ovenstående citater er eksempler på, fremstilles englænderne også som meget fysisk stærke. »Den hårde fight slog os ud. Engloenderne var meget opsatte og stcerkere end svenskerne i norkampene«, vurderede Sepp Piontek i 1988. ${ }^{31}$ En del år senere mente $B T$ ligeledes, at nederlaget ved VM i 2002 bl.a. skyldtes, at Martin Laursen havde haft "problemer over for den fysisk stcerkere og hurtigere Emile Heskey ...«.32

Da Allan Simonsen scorede på straffespark mod England på udebane i EM-kvalifikationen i 1983 fortalte Jyllands-Posten, at »Danmark forvandlede den engelske fodboldløve til en papirstiger «. ${ }^{33}$ Berlingske Tidende mente ligefrem, at løven var blevet tandløs. ${ }^{34}$ Den slags referencer til løver optræder i så stort omfang i den danske presse, at der er tale om et stereotypisk billede af englænderne. Og 2-2-resultatet i 1982 var ifølge Berlingske Tidende så stort, at det ikke kun var de »engelske løver «, der var blevet tvunget i knæ, men nærmere de britiske: »Hvilket drama. Underholdning af dimensioner. 44.300 tilskuere. Fantastisk inspireret dansk spil, der totalt tvang de britiske løver $i$ knce $\ll .{ }^{35}$ Stereotypen, der er identificeret på baggrund af hovedkategorien »Spillet på banen«, beskriver englænderne som slet og ret de bedste, men på samme tid også ordinære. Da Danmark således i sommeren 2002 måtte forlade VM-slutrunden efter nederlag til England, var årsagen, at »Beckham og briterne bare var bedst $\ll{ }^{36}$ Englænderne er altså bare de bedste - men kun til en vis grad. For samtidig med dette billede skaber pressen et modstående af englænderne, der beskriver dem som et ganske ordinært hold. »De spillede en god 1. halvleg, men blev ordincere efter pausen, og så kunne vi såmcend godt ha' vundet den kamp « ${ }^{37}$, mente AaBs træner, Poul-Erik Andreasen i 1992.

På baggrund af den sidste hovedkategori, Spillets struktur, fremstår det stereotypiske billede her som et, der beskriver englændernes velorganiserede optræden på banen. Det udmønter sig ved, at de spiller organisationsfodbold ${ }^{38}$. «Det engelske mandskab er fortsat ikke imponerende på rene boldmoessige kvaliteter. Men holdet er ikke uden chance mod Brasilien eller Belgien på fredag. Primcert på grund af organisationen mod Brasilien som forventet modstander«, lød det efter nederlaget i sommeren 2002. ${ }^{39}$

\section{Den spanske tyr}

Det indbyrdes styrkeforhold mellem det danske og det spanske landshold er siden 1980'erne faldet ud til Spaniens klare fordel. Spanierne har således flere gange været endestation for de danske håb om sportslig succes ved EM- og VM-turneringer samt kvalifikationsrunden til VM. ${ }^{40}$ Pressen tegner et mentalstereotypt billede af spanierne som fightende og snu spillere, og et eksempel på denne fightende indstilling sås, da den spanske landstræner Miguel Muñoz i 1988 beskrev sine spilleres indsats på banen: $»$ Jeg er stolt af mine spillere. De fightede fremragende « ${ }^{41}$ Denne fight suppleres med en koncentreret indsats, der udmønter sig $i$, at spanierne ofte beskrives som snu spillere, der med snilde vinder kampene ${ }^{42}$. Da Danmark var blevet slået ud af VM i 1986 mod Spanien, skrev BT, at »... da danskerne forst var kommet bagud 1-2, og satsede alt på offensivt spil for at komme ind $i$ 
kampen igen, gik det galt. Spanierne var for snu, for gode og for motiverede « ${ }^{43}$

Kigger vi dernæst på det fysiske billede af spanierne, beskriver sportspressen dem som værende hurtige og stærke. Denne hurtighed fremhævede Michael Laudrup i 1995: "... Alkorta er jo en fremragende markeringsspiller. Hurtig, kompromisløs og absolut ikke til at tackle igennem «. ${ }^{44}$ Hurtigheden fremhævedes også i 1980, da Jyllands-Posten skrev, at »Spanien ville vinde, og i 1 . halvleg dominerede de hurtige spanske spillere «. ${ }^{45}$ Men spanierne besidder også stor styrke. Denne styrke fik Danmark i foråret 1984 at føle forud for EM i en venskabskamp, hvor målmand Troels Rasmussen måtte tage sin del af ansvaret for spaniernes 2-1 sejr, men »det var egentligt lidt synd for jyden, thi mellem de stoerke spaniere og et entusiastisk publikum veludrustet med kanonslag havde han gjort det ganske godt«, vurderede Berlingske. ${ }^{46}$ Hovedkategorien Nationale aspekter tegner et billede af Spanien som en tyr og som Danmarks onde ånd. De danske spillerne har således både prøvet at have tyr $\mathrm{i} \mathrm{den}^{47} \mathrm{og}$ tvinge tyren i knæ. ${ }^{48}$ Sidstnævnte i sådan en grad, at de spanske spillere lignede mishandlede tyre. ${ }^{49}$ Danmark har dog oftest fået dødsstødet af tyren, ${ }^{50} \mathrm{og}$ de har prøvet at blive tyret ${ }^{51}$ samt stå over for nådesløse toreadorer: »Bøgetrceet blev foeldet af kun ti spanske tyre i arenaen Estadio Ramon Sanchez Pizjuan i Sevilla [...]. Turen hjem [...] blev lang. Meget langt efter de spanske toreadorers nådesløse totale spaltning og dødsstød på Danmarks europamestre«. ${ }^{52}$ Som nævnt har den onde ånd været prædikatet, den danske sportspresse har påhæftet Spanien siden midtfirserne, som følge af det spanske landsholds evne til besejre det danske i en række afgørende kampe: »Spanien blev atter Danmarks onde ånd. I 1/8-finalen ved VM i Mexico vandt Spanien 5-1 over danskerne, der ellers havde fort 1-0 « ${ }^{53}$, berettede Berlingske Tidende efter det pludselige danske exit fra VM. To år senere var den spanske firedobbelte målscorer fra Mexico, Emilio Butragueño, igen på pletten som »dansk fodbolds onde ånd « ${ }^{54}$, mente målmand Troels Rasmussen.

I hovedkategorien Spillet på banen identificeredes en stereotyp, der beskriver spanierne som bedre teknikere. Som Richard Møller Nielsen efter 0-3 nederlaget i 1994 formulerede det, var »Spanien (...) bedst $i$ alle spillets faser, $i$ angrebet, på midtbanen og i forsvaret. Vi mødte et landshold bestående af en samling fremragende spillere«, vurderede han i $B T^{55}$ Spanierne kan også være utrolig dygtige ${ }^{56}$ og meget boldsikre ${ }^{57}$ og i det hele taget være en klasse over os. ${ }^{58}$ Ved siden af dette disker spanierne op med smarte detaljer, smukt spil ${ }^{59}$ og tekniske finurligheder i et væk: Spanien har et stoerkt mandskab med mange superteknikere, og det er ikke så dårligt at banke dem 1-0 « ${ }^{60}$, mente Peter Schmeichel i april 1993.

I den sidste hovedkategori, Spillets struktur, fremstilles spanierne som organiserede og overlegne spillere. Henrik Andersen udtalte efter EM-kvalifikationskampen i Sevilla i 1994, at den spanske sejr var fortjent, og at "... spanierne var klart overlegne $i$ spillet«. ${ }^{61}$ Organisationen kommer også til udtryk, når spanierne marcherer ${ }^{62}$, og kontrollerer $^{63}$ samt føres an af »Hersker Hierro«. ${ }^{64}$ Det er i øvrigt værd at bemærke, at referencer til Spaniens turbulente politiske fortid med borgerkrig og løsrivelsestendenser i de uafhængige spanske regioner ganske enkelt er ikke-eksisterende i den danske sportspresse. Det hænger sandsynligvis sammen med, at disse forhold er alt for komplicerede at benytte i sportspressen, 
hvor netop sort-hvide fremstillinger foretrækkes.

\section{Den tyske ørn}

Danmark og Tyskland har i perioden 19802004 spillet ni kampe mod hinanden ${ }^{65}$, og til trods for Tysklands store sejre og triumfer på den internationale sportsscene står Danmark i direkte sammenligning med Tyskland bedst $\mathrm{i}$ indbyrdes opgør i perioden. ${ }^{66}$

Det mentalstereotypiske billede af tyskerne i den danske sportspresse er mere sammensat, end tilfældet var med England og Spanien. Det består nemlig af hele tre elementer, idet tyskerne fremstilles som selvtillidsfyldte, arrogante og rådvilde. »Lothar Matthäus [...] struttede af selvtillid ...«, fortalte BT sine læsere i $1986^{67}$, ligesom spillerne optræder selvsikkert ${ }^{68}$ og kombinerer denne indstilling med aggressivite$\operatorname{ten}^{69}$ og deres ustoppelige gå-på-mod. Tyskerne kæmper til sidste sekund ${ }^{70}$ som kampivrige tropper. ${ }^{71}$ Derudover fremstilles de også meget arrogante. Franz Beckenbauer fremstilles, som om han håner Ricardo ${ }^{72}$, og tyskerne tror, de er verdens bedste ${ }^{73}$, de er egoistiske ${ }^{74}$, ja stærkt usympatiske. ${ }^{75} \mathrm{Om}$ det er danskerne, der forvirrer tyskerne, er svært at sige, men faktum er det, at tyskerne ofte fremstilles som rådvilde i kampe mod Danmark $^{76}$, men samtidig besidder de en fænomenal hurtighed og styrke. »De blev ved og ved og ved. Og de kom hele tiden med fuld kraft. Deres contra-spil var hurtigt, effektivt og direkte. Virkelig spillere der var svoere at håndtere«, berettede Lars Olsen i $1988^{77}$. Af citatet anes også tyskernes kolossale styrke ${ }^{78}$, de fremstår som jernmænd $^{79}$, er nærkampsstærke ${ }^{80}$, ja tilmed granithårde. ${ }^{81}$

Ser vi på referencer i sportspressen, der knytter sig til Tyskland som nation, hæfter langt størsteparten af beskrivelserne sig til 2. Verdenskrig. Danskerne var oppe mod et vesttysk »Kraft durch Freude-mandskab $i$ Gelsenkirchen i går «2, hedder det i Politiken i 1988. Ekstra Bladet mente ligeledes efter EM-sejren i 1992, at det var »Dansk fantasi og cool hjerne [der] smadrede den tyske pansermaskine i stumper og stykker. Aldrig $i$ den nerve-sønderflongende gyser fandt de ud af, hvad pokker, der dog skete. Frustrerede, hidsige huggede de til danskerne med alle de dirty tricks, der findes $i$ bogen [...] og et par stykker efter egen speciel germansk opskrift «. ${ }^{83}$ Nogle år tidligere havde Otto Rehhagel, daværende træner for Werder Bremen og under VM i 1986 medkommentator for tysk tv, også berørt den nazistiske fortid. Det skete, da han skulle beskrive de danske tilskueres opførsel, som af mange dengang blev betegnet som eksemplarisk. De danske roligans »optrceden er helt anderledes end de tyske, der har bannere med indskrifter som Slutsejr Berlin«, sagde han. ${ }^{84}$

I hovedkategorien Spillet på banen er der identificeret en stereotyp, der beskriver tyskerne som værende både de bedste og brutale på én og samme tid: »Nu begyndte tyskerne at anvende panzer-noven. »... Den ene gang gik en brutal tackling ud over Arnesen, der var ved at slippe fri $\ll{ }^{85} \mathrm{Men}$ samtidig med at pressen fremstiller tyskerne som brutale, er pressen fascinerede af de tyske spillere. I september 1986 tabte »Danmark [...] 0-2 til et tysk hold, der var klasser bedre end den udbrcendte danske dynamit. Vesttyskerne markerede bedst, var suvercene på midtbanen, stcerkest i norkamp, bedst $i$ luften og havde en bedre boldføling «. ${ }^{86}$ Morten Olsen, daværende anfører på landsholdet, mente ligeledes, at »... tyskerne [fik] en eklatant revanche oven på nederlaget til 
os i Mexico [...] De var bedst på alle punkter $\ll .^{87}$

I den sidste hovedkategori omhandlende Spillets struktur, slår tyskernes organisatoriske talenter igennem. Her beskrives tyskerne som dominerende, men også kontrollerende. »Den tyske dominans var iøjnefaldende«, skrev $B T$ om tyskerne under EM-finalen i 1992, mens Politiken fire år tidligere berettede, at tyskerne "... dominerede [...] så overlegent, at det noermede sig det pinlige for danskerne».

\section{Konklusion}

Samlet set må man om de tre landes mentale stereotyper sige, at der er store forskelle i deres udseende og i den måde, den danske presse fremstiller disse på. Englænderne er aggressive og frustrerede, spanierne snu og fightende, mens tyskerne har meget selvtillid, er arrogante samt rådvilde. Landenes fysiske fremtoning på banen er dog påfaldende identisk, idet hurtighed og styrke knytter sig til alle tre lande. Stereotypen omkring landenes nationale aspekter er derimod forskellig. Englænderne fremstilles som løver, spanierne som tyre og som Danmarks onde ånd, mens tyskerne må høre på referencer til 2. Verdenskrig ofte. De tre landes spil på banen værdsættes højt af den danske sportspresse, der fremhæver, at både Spanien, England og Tyskland slet og ret er de bedste. Englænderne beskrives dog også som ordinære, mens tyskerne anklages for brutalt spil. Der er også meget store ligheder i den måde, landenes spilstruktur beskrives. Alle lande besidder nemlig store organisatoriske evner. Tilmed er Spanien overlegne, mens tyskernes dominans og spilkontrol fremhæves.

Som nævnt forklarer forskningen tilstedeværelsen af de nationale sportsstereoty- per som et resultat af på den ene side fodboldinterne begivenheder, herunder landsholdenes indbyrdes historiske styrkeforhold og aktuelle form, og på den anden side fodboldeksterne begivenheder, så som 2 . Verdenskrig etc. Med hensyn til de fodboldinterne årsager er der næppe tvivl om, at de tre landes flotte sportslige bedrifter gennem tiden er medvirkende til det overordnet set positive billede, pressen skaber. Dernæst spiller den helt aktuelle form antageligt også ind. Hvis tyskerne eksempelvis taber en landskamp mod danskerne, vil kampens resultat $i$ et vist omfang diktere pressens ordvalg.

Med hensyn til fodboldeksterne årsager har nærværende artikel vist, hvordan sådanne forhold også påvirker pressens fremstilling af landene. Tyskerne påhæftes referencer til 2. Verdenskrig, Englænderne referencer til det engelske kongedømme via beskrivelsen af spillerne som løver, mens spaniernes kærlighed til tyrefægtning i høj grad påvirker pressens ordvalg. Sammenligner vi derfor artikels resultater med den eksisterende forskning, ser det ud til, at den danske presse agerer i lighed med resten af den europæiske, og forklaringen herpå er den ret banale, at den danske sportspresse er underlagt de samme konkurrencevilkår som resten af den europæiske presse. Det er nemlig værd at hæfte sig ved, at moderne sport er noget medierne i stort omfang lever af. Sportsjournalisterne er ikke interesserede i, at en given fodboldkamp - næsten uanset, hvor gabende kedelig den har været, fremstilles i avisen som ulidelig. Det skete må vinkles, så dramatikken alligevel er til stede, eller også må det kedsommelige fremstilles som helt exceptionelt uudholdeligt. Her hjælper stereotyperne og sportsjournalistikkens generelle bombastiske sprogbrug, til at nerven er sikret uanset 
kampens udfald og forløb. Hvad angår brugen af stereotyper, er det endvidere i sportsjournalisternes interesse, at disse ikke forandrer sig voldsomt over tid. Stereotyperne er nemlig tidsbesparende arbejdsværktøjer, der er gode at have ved hånden, kort før kampreferatet skal i trykken. Meget belejligt indeholder flere af de stereotyper, der kan identificeres, en iboende dualitet, som gør, at de vil kunne bruges næsten uanset kampens udfald. Tyskerne fremstilles som organisatoriske giganter når de har vundet en kamp, og som uopfindsomme og kedsommelige maskiner, når de taber, netop på grund af deres - ifølge pressens - blinde tro på, at fodboldkampe vindes gennem en stærk organisering. Det er positive karaktertræk, der kan fremhæves, når de besejrer Danmark, men samtidig egenskaber, der kan lægges til grund for eventuelle dårlige resultater. Det samme med spanierne, der portrætteres som aldeles blændende teknikere. De formår at afgøre kampene ved hjælp af netop den suveræne teknik, krydret med deres sydlandske mentalitet. Men netop teknikken kan vendes til noget virkelighedsfjernt og nærmest useriøst, ganske enkelt fordi den solide sikre organisation og overblik i reglen vil være fraværende.

Endelig spiller dansk identitet formentlig ind i forbindelse med pressens fremstilling af de tre lande. Hvis Danmark fremstilles som værende oppe mod overmagten på forhånd, har man fra sportspressens side garderet sig imod et eventuelt nederlag - eller rettere; et nederlag vil være acceptabelt, fordi Danmark er oppe mod de bedste af de bedste. Således kan det tyde på, at stereotyperne er med til at skærme på den ene side sportspressen - der forud for kampen gerne har hyldet det danske landshold, og forventningsfuldt set frem til kampen - og på den anden side selve fodboldlandsholdet mod al for omfattende kritik. Derved vedligeholdes samarbejdet mellem sportspressen og fodboldlandsholdet - netop via stereotypernes konstante hyldest af Danmarks modstandere. For taber Danmark, er det i bund og grund forventeligt, mens en eventuel dansk sejr vil fremstå som endnu større end den $\mathrm{i}$ realiteten er, fordi modstanderholdets styrke forud for kampen så at sige er besunget $\mathrm{i}$ en grad, der nærmest gør et dansk nederlag forventeligt. Samtidig vedligeholdes kontrakten med læserne, der ikke gider købe aviser, der fortæller, at Danmark slog et tamt og kedeligt spansk hold. Læserne vil langt hellere høre om slagne spanske verdensstjerner, der til trods for alle de fænomenale evner, bare ikke var gode nok til de endnu bedre danskere.

\section{Noter}

1 Berlingske Tidende 27.6.1992.

2 Jyllands-Posten 27.6.1992.

3 Berlingske Tidende 14.6.1986. Panzer-næve var et af den tyske værnemagts våben under Anden Verdenskrig.

4 Steinar Eggen og Jørn Fremstad: Fotballjournalistikken i VG og Dagbladet fra 1960-1990. Sport $i$ avis. 7 analyser av norsk sportsjournalistikk.
Thore Roksvold (Red.). (Frederiksstad 1993). pp. 37-69. (særligt pp. 60-61). samt Liz Crolley og David Hand: France and the English Other. Mediation of national identities in post-war football journalism. The Web Journal of French Media Studies. Vol. 4., no.1. (2001). http://wjfms.ncl. ac.uk/enframes.htm

5 Jacques-Philippe Leyens, Vincent Yzerbyt og Ge- 
orges Schadron: Stereotypes and social cognition. (London 1994). pp. 1-8.

6 Se fx Garry Whannel: Individual Stars and Collective Identities in Media Sport. Sport, popular Culture and Identity. Roche, Maurice (Ed.). (Aachen, 2000). p. 28.

7 De kampe, der medtages i analysen er alle Alandsholdkampe. Nærmere bestemt EM- og VMkvalifikationskampe, EM- og VM-slutrundekampe samt venskabskampe. Mod Tyskland, Spanien og England har landsholdet spillet hhv. 9 (19862000), 10 (1980-2004) og 9 kampe (1982-2003).

8 Naturligvis deltager sportspressen også i opvarmningen til kampene, men det er dog efter kampenes afvikling, at sportssiderne i aviserne optager mest spalteplads.

9 Det være sig alt fra interviews, analyser, kamprefererende artikler til baggrundsstof.

10 De enkelte stereotyper er fremkommet ved at udvælge de to antalsmæssigt største underkategorier i hver hovedkategori, på hvilken baggrund en identificering af stereotypen været mulig.

11 Tennissportens nationale sportsstereotyper har eksempelvis været analyseret. Neil Blain og Hugh O'Donnell: The stars and the flags. Individuality, collective identities and the national dimension in Italia '90, and Wimbledon '91 and '92. Games without frontiers: football, identity and modernity. Richard Giulianotti og John Williams (Eds.). (Aldershot, 1994). pp. 245-272. Se også Hugh O'Donnell: Mapping the Mythical: a geopolitics of national sporting stereotypes. Discourse and Society. Vol. 5, no. 3 pp. 345-380. (London, 1994).

12 Liz Crolley og David Hand, 2002, samt Jens Wernecken: Wir und die anderen... Nationale Stereotypen im Kontext des Mediensports. (Berlin, 2000) hører begge til større analyser om emnet.

13 Se fx. Neil Blain, Raymond Boyle og Hugh O'Donnell: Sport and National Identity in the European Media (Leicester, 1993). pp. 55-87. Neil Blain og Hugh O'Donnell i Games without frontiers: football, identity and modernity. Richard Giulianotti og John Williams (Eds.)., 1994. pp. 245-272. EM-1996 behandles bl.a. i Liz Crolley og David Hand, 2002.

14 Liz Crolley, David Hand og Ralf Jeutter: National obsessions and identities in football match reports. Fanatics! Power, identity and fandom in football. Adam Brown (Ed.). (London, 1998). pp. 173-185.

15 Se fx Neil Blain, Raymond Boyle og Hugh O’Donnell, 1993. pp. 55-87.
16 Liz Crolley og David Hand, 2002. pp.89-93 og 143-148.

17 Ibid. pp. 91-92.

18 Ibid. pp. 92-93 og 148.

19 Ibid. pp. 147.

20 Ibid. pp. 57-59.

21 Ibid. p. 58.

22 For en mere uddybet metodisk og teoretisk præsentation af analysens grundlag, henvises til mit speciale, indleveret ved Center for Historie på Syddansk Universitet i maj 2005.

23 Kirsten Frandsen: Dansk Sportsjournalitisk. Fra sport til publikum. (Danmarks Journalisthøjskole, 1995). samt Eggen og Fremstad, 1993.

24 I engelsk presse er kampreferaterne vokset fra 250 ord i 1945 til 5000 ord I år 2000. Optaktsartiklernes længde er vokset fra 275 til 3000 ord i samme periode. Se Liz Crolley og David Hand: France and the English Other. Mediation of national identities in post-war football journalism. The Web Journal of French Media Studies. Vol. 4., no.1. (2001). http://wjfms.ncl.ac.uk/enframes.htm samt fx. Eggen og Fremstad, 1993.

25 Se fx Arthur Hopcraft: The Football Man. People and Passions in Soccer. (London 1968) p.211.

26 Se fx Gunnar Rasmussen: Sportsjournalistik. En pragmatisk og ideologikritisk undersøgelse. (GMT 1974) p.121. Det skal dog nævnes, at også i takt med at nyhederne både i tv og i den trykte presse dramatiseres, indfinder der sig fra tid til anden sportsjournalistisk inspireret sprogbrug på de mere »seriøse« sider i avisen, på internettet og i tv.

27 BT 16.5.1990

28 Ekstra Bladet 12.6.1992

29 Berlingske Tidende 23.9.1982.

30 Berlingske Tidende 16.5.1990.

31 BT 15.9.1988.

32 BT 16.6.2002.

33 Jyllands-Posten 22.9.1983

34 Berlingske Tidende 22.9.1983.

35 Berlingske Tidende 23.9.1982

36 Jyllands-Posten 16.6.2002.

37 Ekstra Bladet 12.6.1992.

38 BT 16.6.2002.

39 BT 16.6.2002.

40 Spanien slog Danmark ud af EM i 1984, VM 1986, og under EM 1988 besejrede Spanien Danmark i gruppespillet. Det spanske landshold vandt også den afgørende kamp om kvalifikation til VM-slutrunden i USA i 1994. Før 1980 havde landsholdene mødtes fire gange, hvoraf Spanien har vundet de tre. 
41 Ekstra Bladet 12.6.1988.

42 BT 25.6.1984 og 12.6.1988.

43 BT 19.6.1986.

44 BT 12.10.1995.

45 Jyllands-Posten 22.5.1980.

46 Berlingske Tidende 12.4.1984.

47 Ekstra Bladet 1.4.1993.

48 Jyllands-Posten 25.6.1984 og 19.6.1986.

49 BT 1.4.1993.

50 Ekstra Bladet 18.11.1993.

51 Politiken 12.6.1988.

52 Berlingske Tidende 18.11.1993.

53 Berlingske Tidende 19.6.1986.

54 Ekstra Bladet 12.6.1988.

55 BT17.11.1994.

56 Ekstra Bladet 12.10.1995.

57 Ekstra Bladet 12.6.1988 og BT 22.5.1980.

58 Ekstra Bladet 17.11.1994.

59 BT 1.4.1993.

60 BT 1.4.1993.

61 Jyllands-Posten 12.10.1995.

62 Ekstra Bladet 17.11.1994.

63 BT 18.11.1993.

64 Berlingske Tidende 18.11.1993.

65 Den første i 1986, den sidste i 2000.

66 Før 1980 er det sportslige styrkeforhold jævnt. Så- ledes er det først i 1986 at Danmark og Tyskland spiller en pointkamp mod hinanden. Før da havde landene kun spillet venskabskampe.

67 BT 25.9.1986.

68 Politiken 14.6.1986.

69 Se fx Jyllands-Posten 14.6.1986 og Politiken 15.6.1988.

70 BT 27.6.1992.

71 Jyllands-Posten 27.6.1992.

72 Ekstra Bladet 31.5.1990.

73 BT 16.11.2000.

74 BT 10.9.1992.

75 BT 10.9.1992.

76 Politiken 27.6.1992. Samt fx BT 14.6.1986, BT 24.9.1987, Politiken 27.6.1992 og BT 16.11.2000.

77 Politiken 15.6.1988.

78 Politiken 15.6.1988.

79 Jyllands-Posten 27.6.1992.

80 Jyllands-Posten 25.9.1986.

81 BT 14.6.1986.

82 Politiken 15.6.1988.

83 Ekstra Bladet 27.6.1992.

84 Politiken 14.6.1986.

85 Berlingske Tidende 14.6.1986

86 Berlingske Tidende 25.9.1986.

87 Berlingske Tidende 25.9.1986.

\section{Litteraturliste}

Blain, N, Boyle, R \& O'Donnell, H: Sport and National Identity in the European Media (Leicester, 1993).

Blain, N \& O'Donnell, H: The stars and the flags. Individuality, collective identities and the national dimension in Italia '90, and Wimbledon' '91 and '92. I: Giulianotti, R \& Williams, J (Eds.): Games without frontiers: football, identity and modernity (Aldershot, 1994).

Crolley, L, Hand, D \& Jeutter, R: National obsessions and identities in football match reports. I: Adam Brown (Ed.): Fanatics! Power, identity and fandom in football (London, 1998).

Crolley, L \& Hand, D: France and the English Other. Mediation of national identities in post-war football journalism. I: The Web Journal of French Media Studies. Vol. 4, no.1. (2001).

Crolley, L \& Hand, D: Football, Europe and the press. (London, 2002).

Eggen, S \& Fremstad, J: Fotballjournalistikken i VG og Dagbladet fra 1960-1990. I: Roksvold, Thore (Red.) Sport i avis. 7 analyser av norsk sportsjournalistikk (Frederiksstad 1993).

Frandsen, K: Dansk Sportsjournalitisk. Fra sport til publikum. (Danmarks Journalisthøjskole, 1995).

Hopcraft, A: The Football Man. People and Passions in Soccer. (London 1968).

Leyens, J-P, Yzerbyt, V \& Schadron, G: Stereotypes and social cognition (London 1994).

O'Donnell, H: Mapping the Mythical: a geopolitics of national sporting stereotypes. I: Discourse and Society, vol. 5. no.3 (London, 1994).

Rasmussen, G: Sportsjournalistik. En pragmatisk og ideologikritisk undersøgelse (GMT 1974).

Wernecken, J: Wir und die anderen... Nationale Stereotypen im Kontext des Mediensports. (Berlin, 2000).

Whannel, G: Individual Stars and Collective Identities in Media Sport. I: Roche, M (Ed.): Sport, Popular Culture and Identity (Aachen, 2000).

Herudover er benyttet følgende aviser: Berlingske Tidende, Ekstra Bladet, BT, Politiken og JyllandsPosten. Derudover http://wjfms.ncl.ac.uk/enframes.htm 